Topik: Ilmu Geografi

\title{
Mortalitas di Indonesia (Sejarah Masa Lalu dan Proyeksi ke Depan)
}

\author{
Muhammad Arif Fahrudin Alfana ${ }^{1}$, Widha Ayu Nur Permata Hanif ${ }^{2}$ dan Maulida Iffani ${ }^{3}$ \\ ${ }^{1}$ Fakultas Geografi, Sekip Bulaksumur Yogyakarta, arif.fahrudin@ugm.ac.id \\ ${ }^{2}$ Fakultas Geografi, Sekip Bulaksumur Yogyakarta, widha.ayu3@gmail.com \\ ${ }^{3}$ Fakultas Geografi, Sekip Bulaksumur Yogyakarta, maulida.iffani@yahoo.com
}

\begin{abstract}
Abstrak
Mortalitas merupakan bagian dari kajian kependudukan yang menarik untuk dibahas karena selalu menjadi salah satu target dalam pembangunan manusia suatu negara. Indonesia merupakan salah satu negara yang menggunakan mortalitas sebagai tolak ukur pembangunan manusianya. Tujuan dari penelitian ini adalah untuk melihat dinamika perubahan parameter mortalitas yang ada di Indonesia. Parameter tersebut digunakan untuk melihat bagaimana tren perkembangan pada tahun lalu, pencapaian saat ini dan proyeksi di masa yang akan datang. Parameter mortalitas yang digunakan dalam penelitian ini meliputi angka kematian bayi, angka kematian anak dan angka harapan hidup. Ketiga parameter ini merupakan indikator negatif yang sering digunakan sebagai patokan dalam melihat pencapaian pembangunan manusia khususnya dalam bidang mortalitas.

Penelitian ini berdasarkan populasinya merupakan penelitian sampling. Data yang digunakan dalam penelitian ini adalah data sekunder yang bersumber dari BPS dan UN. Analisis data dilakukan dengan analisis deskriptif kuantitatif. Hasil penelitian menunjukkan bahwa indikator mortalitas di Indonesia terus mengalami tren positif sejak 1950 sampai sekarang. Hal ini menunjukkan derajat kesehatan di Indonesia mengalami perbaikan dari waktu ke waktu. Berdasarkan parameternya angka kematian bayi, angka kematian anak, dan harapan hidup menujukkan tren yang positif dimana target dari ICPD dan WHO telah terpenuhi. Secara nasional, tren positif tersebut diproyeksikan akan terus membaik sampai tahun 2050. Meskipun demikian jika dilihat berdasarkan provinsinya, beberapa provinsi belum memenuhi target yang ditetapkan oleh ICPD dan WHO. Kurangnya tenaga fasilitas kesehatan, keterbatasan sarana prasarana kesehatan dan kurangnya dukungan dana untuk kesehatan menjadi penyebab beberapa provinsi tidak mampu memenuhi target tersebut.
\end{abstract}

Kata kunci: proyeksi, mortalitas, Indonesia 


\section{Seminar Nasional dan PIT IGI XVIII 2015}

\section{PENDAHULUAN}

Dokumen International Conference on Population and Developmant (ICPD) yang dirumuskan pada 1994 dan disepakati oleh 179 negara menyebutkan bahwa permasalahan kependudukan yang terjadi di sebagian besar penduduk dunia harus segera diselesaikan. Permasalahan tersebut meliputi pertumbuhan penduduk yang tinggi, IMR dan CMR yang tinggi, fertilitas dan KB, kesehatan reproduksi dan ibu hamil, akses pendidikan yang terbatas, permasalahan lansia serta permasalahan imigrasi dan urbanisasi. Dari permasalahan-permasalahan tersebut, mortalitas menjadi salah satu kajian yang sangat menarik untuk dibahas karena selalu menjadi salah satu target dalam pembangunan manusia satu negara (UNFPA, 2004).

Berbagai indikator disusun untuk melihat seberapa besar pencapaian pembangunan manusia dalam kaitannya dengan mortalitas. Tercatat dalam beberapa kesepakatan internasional target beberapa indikator mortalitas menjadi pagu yang harus dicapai bagi tiap-tiap negara di dunia, termasuk di dalamnya adalah dokumen ICPD pada 1994 dan MDGs pada tahun 2000. Indikator mortalitas yang digunakan sebagai kesepakatan tersebut meliputi angka harapan hidup, angka kematian bayi, angka kematian balita, angka kematian ibu dan HIV/AIDS.

Indonesia sebagai bagian dari negara-negera dunia memiliki kewajiban untuk mencapai target yang telah disepakati bersama. Dalam hal ini target dari indikator mortalitas sebagai salah satu komponen pembangunan manusia harus dicapai sebagai wujud komitmen terhadap dunia internasional. Misalnya salah satu target mortalitas adalah angka harapan hidup. Pada 1977 dalam "Resolusi WHO dengan tema Health for all by 2000" menyatakan bahwa pada tahun 2000 seluruh negara-negara di dunia harus mencapai rata-rata angka harapan hidup bagi warganya menjadi 60 tahun. Target pencapaian angka harapan hidup tersebut kemudian meningkat pada kesepakatan global berikutnya yaitu ICPD tahun 1994. Dalam kesepakatan bersama dalam ICPD disebutkan bahwa seluruh negara-negara di dunia harus mencapai rata-rata angka harapan hidup bagi warganya menjadi berumur lebih dari 65 tahun pada tahun 2005 dan pada tahun 2015 rata-rata angka harapan hidup menjadi lebih dari 70 tahun. Target angka harapan hidup yang telah ditetapkan tersebut harus dipenuhi bagi Indonesia agar pembangunan manusianya tidak tertinggal dari bangsa-bangsa lain di dunia. Selain angka harapan hidup, target indikator lainnya juga harus dipenuhi. Tabel 1 merupakan target indikator-indikator mortalitas dalam kesepakatan global dari 1977-2000. 


\section{Seminar Nasional dan PIT IGI XVIII 2015}

Tabel 1. Target Indikator Mortalitas dalam Kesepakatan Global 1977-2000

\begin{tabular}{|c|c|c|c|}
\hline \multirow{2}{*}{ Indikator Mortalitas } & \multicolumn{3}{|c|}{ Target } \\
\hline & $\begin{array}{l}\text { Resolusi WHO "Health for All by } \\
\text { 2000" (1977) }\end{array}$ & ICPD Program (1994) & MDGs (2000) \\
\hline \multirow{3}{*}{ Angka Harapan Hidup } & \multirow{3}{*}{$\begin{array}{l}\text { Tercapainya angka harapan hidup } \\
\text { lebih dari } 60 \text { tahun pada tahun } 2000\end{array}$} & $\begin{array}{l}\text { Tercapainya AHH lebih besar dari } 70 \text { pada } \\
\text { tahun } 2005 \text { dan lebih tinggi dari } 75 \text { pada } 2015\end{array}$ & \\
\hline & & $\begin{array}{l}\text { Bagi negara dengan tingkat mortalitas tinggi, } \\
\text { tercapainya AHH lebih besar dari } 65 \text { tahun } \\
\text { pada } 2005 \text { dan lebih tinggi dari } 70 \text { pada tahun }\end{array}$ & \\
\hline & & 2015 & \\
\hline \multirow[t]{2}{*}{ Angka Kematian Bayi } & \multirow[t]{2}{*}{$\begin{array}{l}\text { Tercapainya angka IMR kurang dari } \\
50 \text { per } 1000 \text { kelahiran hidup pada } \\
\text { tahun } 2000\end{array}$} & $\begin{array}{l}\text { Mengurangi IMR sebanyak sepertiga atau } \\
\text { menjadi } 50 \text { per } 1000 \text { kelahiran hidup, atau } \\
\text { lebih rendah dari nilai tersebut pada tahun } \\
2000\end{array}$ & \\
\hline & & $\begin{array}{l}\text { Tercapainya IMR kurang dari } 35 \text { per } 1000 \\
\text { kelahiran hidup pada } 2015\end{array}$ & \\
\hline \multirow[t]{2}{*}{ Angaka Kematian Balita } & \multirow[t]{2}{*}{$\begin{array}{l}\text { Tercapainya nilai CMR kurang dari } \\
70 \text { per } 1000 \text { kelahiran hidup pada } \\
\text { tahun } 2000\end{array}$} & $\begin{array}{l}\text { Mengurangi CMR menjadi sepertiganya atau } \\
\text { menjadi } 70 \text { per } 1000 \text { kelahiran hidup atau } \\
\text { lebih rendah dari nilai tersebut pada tahun } \\
2000\end{array}$ & \multirow[t]{2}{*}{$\begin{array}{l}\text { Mengurangi angka CMR sebanyak } \\
2 / 3 \text { pada tahun } 2015 \text { dari tahun } \\
\text { dasar } 1990\end{array}$} \\
\hline & & $\begin{array}{l}\text { Tercapainya CMR kurang dari } 45 \text { per } 1000 \\
\text { kelahiran hidup pada tahun } 2015\end{array}$ & \\
\hline \multirow{3}{*}{ Maternal Mortality } & \multirow{3}{*}{$\begin{array}{l}\text { Mengurangi angka MMR menjadi } \\
\text { setengahnya pada tahun } 2000 \text { dari } \\
\text { nilai MMR pada tahun } 1978\end{array}$} & $\begin{array}{l}\text { Mengurangi nilai MMR menjadi setengahnya } \\
\text { pada tahun } 2000 \text { dari tahun dasar } 1990 \text { dan } \\
\text { menjadi separo lebih pada tahun } 2015\end{array}$ & \multirow{3}{*}{$\begin{array}{l}\text { Mengurangi nilai MMR menjadi } \\
\text { 3/4 pada tahun } 2015 \text { dari tahun } \\
\text { dasar } 1990\end{array}$} \\
\hline & & $\begin{array}{l}\text { Pada negara dengan level mortalitas } \\
\text { intermediate, tercapainya MMR kurang dari } \\
100 \text { per } 100000 \text { kelahiran hidup pada tahun } \\
2005 \text { dan kurang dari } 60 \text { per } 100000 \text { kelahiran } \\
\text { hidup pada tahun } 2015\end{array}$ & \\
\hline & & $\begin{array}{l}\text { Pada negara dengan level mortalitas yang } \\
\text { tinggi, tercapainya MMR kurang dari } 125 \text { per } \\
100000 \text { kelahiran hidup pada tahun } 2005 \text { dan } \\
\text { kurang dari } 75 \text { per } 100000 \text { kelahiran hidup } \\
\text { pada tahun } 2015\end{array}$ & \\
\hline \multirow[b]{2}{*}{ HIV/AIDS } & & & $\begin{array}{l}\text { Lebih sehat dan mengendalikan } \\
\text { penyebaran HIV/AIDS pada } 2015\end{array}$ \\
\hline & & & $\begin{array}{l}\text { Tercapainya akses secara } \\
\text { menyeluruh untuk pengobatan } \\
\text { bagi semua pada tahun } 2010\end{array}$ \\
\hline
\end{tabular}

Sumber: UN, 2013

Target yang telah disepakati harus dipenuhi oleh Indonesia. Pertanyaannya adalah apakah selama ini Indonesia telah berhasil melewati target-target tersebut? Selain itu dengan jumlah provinsi yang banyak dengan karakteristik wilayah dan tingkat pembangunan yang berbeda tentu juga berpengaruh dalam pencapaian di tiap-tiap provinsi. Berdasarkan alasan tersebut maka dibutuhkan analisis tren perkembangan pembangunan manusia dalam kaitannya dengan mortalitas. Analisis tren merupakan suatu metode analisis yang ditujukan untuk melakukan suatu estimasi atau peramalan pada masa yang akan 


\section{Seminar Nasional dan PIT IGI XVIII 2015}

datang dengan melihat kejadian yang telah terjadi di masa lalu. Untuk itu maka dibutuhkan berbagai macam informasi (data) yang cukup banyak dan diamati dalam periode waktu yang relatif cukup panjang, sehingga hasil analisis tersebut dapat mengetahui sampai berapa besar fluktuasi yang terjadi dan faktorfaktor apa saja yang memengaruhi terhadap perubahan tersebut. Hal ini menjadi penting sebagai salah satu langkah dalam penciptaan pembangunan yang berkelanjutan yang tepat sasaran khususnya dalam bidang pembangunan manusia dalam kaitannya dengan mortalitas. Berdasarkan hal tersebut, maka rumusan masalah dalam penelitian ini adalah:

1. Bagaimana capaian parameter mortalitas di Indonesia saat ini dan pada masa lalu jika dilihat dari target kesepakatan internasional tentang pembangunan manusia?

2. Bagaimanakah perbandingan parameter mortalitas antar provinsi di Indonesia?

3. Bagaimana proyeksi parameter-parameter mortalitas di Indonesia pada masa yang akan datang? Dengan berpijak pada hal tersebut maka ditentukan judul penelitian Mortalitas di Indonesia (Sejarah Masa Lalu dan Proyeksi ke Depan).

\section{TINJAUAN PUSTAKA}

1. Konsep Mortalitas

Kematian atau mortalitas merupakan salah satu dari tiga komponen proses demografi yang berpengaruh terhadap struktur penduduk, dua komponen yang lainnya adalah kelahiran (fertilitas) dan mobilitas penduduk (Mantra, 2000). Menurut Utomo (1985) kematian dapat diartikan sebagai peristiwa hilangnya semua tanda-tanda kehidupan secara permanen, yang bisa terjadi setiap saat setelah kelahiran hidup.

Menurut PBB dan WHO, kematian adalah hilangnya semua tanda-tanda kehidupan secara permanen yang bisa terjadi setiap saat setelah kelahiran hidup. Still birth dan keguguran tidak termasuk dalam pengertian kematian. Perubahan jumlah kematian (naik turunnya) di tiap daerah tidaklah sama, tergantung pada berbagai macam faktor keadaan. Besar kecilnya tingkat kematian ini dapat merupakan petunjuk atau indikator bagi tingkat kesehatan dan tingkat kehidupan penduduk di suatu wilayah.

Konsep-konsep lain yang terkait dengan pengertian mortalitas adalah:

a. Neo-natal death adalah kematian yang terjadi pada bayi yang belum berumur satu bulan.

b. Lahir mati (still birth) atau yang sering disebut kematian janin (fetal death) adalah kematian sebelum dikeluarkannya secara lengkap bayi dari ibunya pada saat dilahurkan tanpa melihat lamanya dalam kandungan.

c. Post neo-natal adalah kematian anak yang berumur antara satu bulan sampai dengan kurang dari satu tahun.

d. Infant death (kematian bayi) adalah kematian anak sebelum mencapai umur satu tahun. 


\section{Seminar Nasional dan PIT IGI XVIII 2015}

\section{Faktor Pengaruh dalam Mortalitas}

Faktor-faktor yang mempengaruhi kematian dibagi menjadi dua yaitu:

1. Faktor langsung (faktor dari dalam), faktor tersebut antara lain dipengaruhi oleh beberapa variabel yaitu:
a. Umur,
b. Jenis kelamin,
c. Penyakit,
d. Kecelakaan, kekerasan, bunuh diri.

2. Faktor tidak langsung (faktor dari luar), faktor tersebut antara lain dipengaruhi oleh beberapa variabel yaitu:
a. Tekanan, baik psikis maupun fisik,
b. Kedudukan dalam perkawinan,
c. Kedudukan sosial-ekonomi,
d. Tingkat pendidikan,
e. Pekerjaan,
f. Beban anak yang dilahirkan,
g. Tempat tinggal dan lingkungan,
h. Tingkat pencemaran lingkungan,
i. Fasilitas kesehatan dan kemampuan mencegah penyakit,
j. Politik dan bencana alam.

\section{Indikator Mortalitas}

Indikator mortalitas merupakan angka atau indeks, yang di pakai sebagai dasar untuk menentukan tinggi rendahnya tingkat kematian suatu penduduk. Ada berbagai macam ukuran kematian, mulai dari yang paling sederhana sampai yang cukup kompleks. Namun demukian perlu di catat bahwa keadaan kematian suatu penduduk tidaklah dapat diwakili oleh hanya suatu angka tunggal saja. Biasanya berbagai macam ukuran kematian di pakai sekaligus guna mencerminkan keadaan kematian penduduk secara keseluruhan. Hampir semua ukuran kematian merupakan suatu "rate" atau "ratio". Rate merupakan suatu ukuran yang menunjukkan terjadinya suatu kejadian (misalnya: kematian, kelahiran, sakit, dan sebagainya) selama peroide waktu-waktu tertentu.

Kematian (mortalitas) adalah peristiwa hilangnya semua tanda-tanda kehidupan secara permanen yang bisa terjadi tiap saat setelah kelahiran hidup. (Budi Utomo, 1985). Morbiditas (penyakit/kesakitan) adalah kondisi penyimpangan dari keadaan yang normal, yang biasanya dibatasi pada kesehatan fisik dan 


\section{Seminar Nasional dan PIT IGI XVIII 2015}

mental. Pada kasus tertentu morbiditas ini terjadi secara terus menerus (morbiditas kumulatif) yang pada akhirnya dapat menyebabkan kematian pada penderitanya.

Ada beberapa cara pengukuran angka kematian diantaranya adalah:

\section{a. Tingkat Kematian Kasar (Crude Death Rate)}

adalah banyaknya kematian pada tahun tertentu, tiap 1000 penduduk pada pertengahan tahun.

Dimana :

$$
\mathrm{CDR}=\mathrm{D} / \mathrm{P} \times 100
$$

$\mathrm{D}=$ jumlah kematian pada tahun $\mathrm{X}$

$\mathrm{Pm}=$ jumlah penduduk pada pertengahan tahun $\mathrm{x}$

$\mathrm{k}=$ konstanta 1000

Tingkat kematian ini dapat digolongkan dalam kriteria sebagai berikut:

Tingkat kematian Golongan

$>18$ Tinggi

14-18 Sedang

9-13 Rendah

b. Tingkat Kematian Menurut Umur ( Age Specific Death Rate )

adalah jumlah kematian penduduk pada tahun tertentu berdasarkan klasifikasi umur tertentu.

$\mathrm{ASDR}=\mathrm{Di} / \mathrm{Pmi} \times \mathrm{k}$

Dimana :

Di $=$ Jumlah kematian pada kelompok umur (i)

Pmi $=$ Jumlah penduduk pada pertengahan tahun pada kelompok umur (i)

$\mathrm{k}=$ Angka konstan (1000)

\section{c. Tingkat Kematian Bayi \{ Infant Death Rate (IDR) /Infat Mortality Rate (IMR)}

Bayi (infant) merupakan orang yang berumur 0 (nol) tahun atau dalam kata lain anak-anak yang masih belum sampai pada hari ulang tahunnya yang pertama. Angka kematian bayi merupakan variable sosial ekonomis dan demografis yang sangat penting karena data tersebut dapat menunjukan banyaknya fasilitas medis dan taraf kehidupan penduduk. 


$$
\mathrm{IMR}=\mathrm{D} 0 / \mathrm{B} \times 1000
$$

Dimana :

Do $=$ Jumlah kematian bayi pada tahun tertentu

$\mathrm{B}=\mathrm{Jumlah}$ lahir hidup pada tahun tertentu

$\mathrm{k}=$ bilangan konstan (1000)

Kriteria penggolongan tingkat kematian bayi:

Tingkat kematian bayi Golongan

> 125 Sangat Tinggi

75-125 Tinggi

35-75 Sedang

$<35$ Rendah

\section{d. Tingkat Kematian Anak}

Tingkat kematian anak didefinisikan sebagai jumlah kematian anak berumur 1 sampai 4 tahun selama 1 tahun tertentu per 1000 anak umur yang sama pada pertengahan tahun. Dengan demikian, angka kematian anak tidak menyertakan angka kematian bayi. Angka kematian anak lebih merefleksikan kondisi kesehatan lingkungan yang langsung mempengaruhi tingkat kesehatan anak.

\section{e. Angka Kematian Ibu}

Adalah jumlah kematian ibu karena kehamilan, persalinan, dan nifas dalam satu tahun dibagi dengan jumlah kelahiran hidup pada tahun yang sama dengan persen atau permil.

Rumus:

$$
\mathrm{AKI}=\mathrm{Pf} / \mathrm{P} \times 100
$$

AKI = Jumlah kematian ibu karena kehamilan, kelahiran dan nifas X100

$\mathrm{P} \quad=$ Jumlah kelahiran hidup pada tahun yang sama 


\section{Seminar Nasional dan PIT IGI XVIII 2015}

\section{Sumber Data Mortalitas}

Cara mengetahui sumber data kematian dapat diperoleh dari berbagai macam sumber, antara lain :

a. Sistem registrasi vital

Apabila sistem ini bekerja dengan baik merupakan sumber data kematian yang ideal. Di sini, kejadian kematian dilaporkan dan dicatat segera setelah peristiwa kematian tersebut terjadi. Di Indonesia, belum ada sistem registrasi vital yang bersifat nasional, yang ada hanya sistem registrasi vital yang bersifat bersifat lokal, dan hal ini tidak sepenuhnya meliputi semua kejadian kematian pada kota-kota itu sendiri. Dengan demikian di Indonesia tidak mungkin memperoleh data kematian yang baik dari sistem registrasi vital.

b. Sensus dan survei penduduk

Sensus dan survei penduduk merupakan kegiatan sesaat yang bertujuan untuk mengumpulkan data penduduk, termasuk pula data kematian. Berbeda dengan sistem registrasi vital, pada sensus atau survei kejadian kematian dicacat setelah sekian lama peristiwa kejadian itu terjadi. Data ini diperoleh melalui sensus atau survei dapat digolongkan menjadi dua bagian :

Bentuk langsung (Direct Mortality Data)

Data kematian bentuk langsung diperoleh dengan menanyakan kepada responden tentang ada tidaknya kematian selama kurun waktu tertentu. Apabila ada tidaknya kematian tersebut dibatasi selama satu tahun terakhir menjelang waktu sensus atau survei dilakukan, data kematian yang diperoleh dikenal sebagai 'Current mortality Data'.

Bentuk tidak langsung (Indirect Mortalilty Data)

Data kematian bentuk tidak langsung diperoleh melalui pertanyaan tentang 'Survivorship' golongan penduduk tertentu misalnya anak, ibu, ayah dan sebagainya. Dalam kenyatana data ini mempunyai kualitas lebih baik dibandingkan dengan data bentuk langsung. Oleh sebab itu data kematian yang sering dipakai di Indonesia adalah data kematian bentuk tidak langsung dan biasanya yaitu data 'Survivorship' anak. Selain sumber data di atas, data kematian untuk penduduk golongan tertentu di suatu tempat, kemungkinan dapat diperoleh dari rumah sakit, dinas pemakaman, kantor polisi lalu lintas dan sebagainya.

c. Penelitian

Penelitian kematian penduduk biasanya dilakukan bersamaan dengan penelitian kelahiran yang disebut dengan penelitian statistik vital.

d. Perkiraan (estimasi)

Tingkat kematian dapat diperkirakan menggunakan pendekatan tidak langsung. Pendekatan tidak langsung tersebut dilakukan dengan cara mengamati tahapan kehidupan dari waktu ke waktu. Pendekatan tidak langsung ini memiliki tiga kesulitan utama yaitu terbatasnya sumberdaya untuk memastikan data dan disertai kesalahan pada sampling, tingkat mobilitas remaja yang tinggi menyebabkan remaja terhindar dari sampling, dan tidak perkiraan struktur kematian yang tidak mudah (Wood dan Nisbet, 1990). 


\section{TUJUAN PENELITIAN}

Tujuan yang ingin dicapai dalam penelitian ini antara lain untuk melihat dinamika parameterparameter mortalitas di Indonesia. Rentang waktu yang digunakan adalah dari 1950-20. Hal itu meliputi bagaimana gambaran mortalitas pada masa lalu terkait dengan perbandingan dengan capaian yang harus dilaksanakan sesuai dengan kesepakatan internasional. Kedua adalah untuk mengetahui dinamika indikator mortalitas antar provinsi di Indonesia. Tujuan ke tiga adalah untuk melihat proyeksi di masa yang akan datang sampai 2050.

\section{METODE PENELITIAN}

Penelitian ini merupakan suatu kajian mengenai dinamika mortalitas di Indonesia pada masa lalu dan proyeksi ke depan berdasarkan data dari publikasi UN dan Sensus dari BPS Indonesia. Penelitian ini berdasarkan obyeknya merupakan penelitian survei dengan metode kuantitatif untuk analisisnya. Sedangkan berdasarkan eksistensi populasinya, penelitian ini menggunakan metode sampling.

\subsection{Pemilihan Lokasi Daerah Penelitian}

Daerah yang diteliti adalah Indonesia dengan unit analisis provinsi. Pertimbangan unit analisis sampai ke provinsi adalah untuk melihat dinamika indikator mortalitas sampai daerah terkecil yang masih dapat tercover oleh data. Penyusun membatasi ruang lingkupnya hanya membahas bagaimanakah perbandingan dinamika indikator mortalitas di provinsi di Indonesia pada 1971-2010 menurut data sensus. Sedangkan untuk mengetahui tren masa lalu dari tahun 1950 sampai proyeksi pada 20500 unit yang dianalisis adalah Indonesia secara keseluruhan melalui data dari UN.

\subsection{Alat dan Bahan Penelitian}

Peralatan dan bahan yang dibutuhkan untuk mendukung pelaksanaan kegiatan ini adalah:

(a) Data indikator mortalitas seperti IMR, CMR, MMR dan angka harapan hidup yang bersumber dari Biro Pusat Statistik (BPS) dan UN;

(b) Berbagai sumber data instansional, seperti: Data Publikasi dari Dinas Sosial dan instansi lainnya;

(c) Peta-peta tematik hasil kajian yang terkait;

(d) Data penelitian sebelumnya, seperti: jurnal, laporan penlitian, paper, skripsi, tesis, desertasi, dan lainnya;

(e) Peralatan untuk penyusunan laporan dan pemetaan, meliputi:, scanner, dan komputer analisis dengan perangkat lunak ArcView dan MS Office.. 


\section{Seminar Nasional dan PIT IGI XVIII 2015}

\subsection{Metode Pengumpulan Data}

Metode pengumpulan data dilakukan dengan menggunakan metode kualitatif. Data yang digunakan dalam penyusunan laporan ini bersumber dari data UN, khususnya data IMR, CMR, MMR dan angka harapan hidup dikumpulkan dari periode 1950-2050.

\subsection{Metode Perhitungan}

Data yang digunakan merupakan hasil publikasi BPS dan UN dalam berbagai rentang waktu. Data yang diperoleh akan dihitung dengan rumus sebagai berikut:

a. Tingkat Kematian Kasar (Crude Death Rate)

adalah banyaknya kematian pada tahun tertentu, tiap 1000 penduduk pada pertengahan tahun.

$$
\mathrm{CDR}=\mathrm{D} / \mathrm{P} \times 100
$$

Dimana :

$\mathrm{D}$ = jumlah kematian pada tahun $\mathrm{X}$

$\mathrm{Pm}=$ jumlah penduduk pada pertengahan tahun $\mathrm{x}$

$\mathrm{k}=$ konstanta 1000

b. Tingka Kematian Anak

Tingkat kematian anak didefinisikan sebagai jumlah kematian anak berumur 1 sampai 4 tahun selama 1 tahun tertentu per 1000 anak umur yang sama pada pertengahan tahun. Dengan demikian, angka kematian anak tidak menyertakan angka kematian bayi. Angka kematian anak lebih merefleksikan kondisi kesehatan lingkungan yang langsung mempengaruhi tingkat kesehatan anak.

c. Tingkat Kematian Bayi \{ Infant Death Rate (IDR) /Infant Mortality Rate (IMR)

Angka kematian bayi dapat dihitung dengan rumus sebagai berikut:

$$
\mathrm{IMR}=\mathrm{D} 0 / \mathrm{B} \times 1000
$$

Dimana :

Do $=$ Jumlah kematian bayi pada tahun tertentu

$\mathrm{B}=$ Jumlah lahir hidup pada tahun tertentu

$\mathrm{k}=$ bilangan konstan (1000) 
Seminar Nasional dan PIT IGI XVIII 2015

\subsection{Teknik Analisis Data}

Analisa data adalah kegiatan mengubah data hasil penelitian menjadi informasi yang dapat digunakan untuk mengambil kesimpulan dalam suatu penelitian. Adapun analisis data yang digunakan dalam penelitian ini menggunakan analisis deskriptif dan analisis komparasi

1. Analisis Deskriptif

Permalasalahan yang akan di kaji di dalam penelitian ini di jelaskan dengan menggunakan analisis desrkriptif. Analisis deskriptif akan mengorganisasi dan menganalisa data dari indikator-indikator IMR, CMR, MMR dan angka harapan hidup agar dapat memberikan gambaran secara jelas, teratur dan ringkas sehingga dapat ditarik kesimpulan. Penyajian data tersebut akan disajikan dalam bentuk tabel dan grafik.

2. Analisis Komparasi

Tujuan dari di lakukannya analisis komparasi ini adalah untuk membandingkan perubahan pencapaian indikator-indikator mortalitas di Indonesia tahun 1971-2010. Selain itu analisis ini juga bertujuan untuk membandingkan pencapaian indikator-indikator mortalitas pada lingkup provinsi. Dengan membandingkan dalam cakupan provinsi maka akan dapat diketahui ketertinggalan maupun kemajuan provinsi terhadap nasional. Provinsi dikatakan baik apabila memiliki nilai indeks di atas 100, sedangkan dikatakan tertinggal apabila nilai indeks dibawah 100.

\section{PEMBAHASAN}

Indikator mortalitas merupakan ukuran-ukuran yang menggambarkan nilai kematian di suatu tempat. Indikator tersebut terdiri dari indikator mortalitas positif dan indikator negatif (Tukiran, 2010). Indikator mortalitas yang dibahas pada tulisan ini adalah indikator negatif yang terdiri dari angka kematian kasar, angka kematian bayi, angka kematian balita dan angka harapan hidup.

\subsection{Angka Kematian Kasar}

Kondisi mortalitas di Indonesia secara umum digambarkan melalui angka kematian kasar atau Crude Death Rate (CDR). Besarnya CDR mencerminkan banyaknya kematian pada tahun tertentu setiap 1000 penduduk pada pertengahan tahun. CDR memberikan informasi tentang keadaan kematian suatu Negara tanpa mempertimbangkan umur, jenis kelamin, dan kriteria-kriteria tertentu melainkan keadaan kematian secara keseluruhan. Keadaan angka kematian kasar di Indonesia dari periode 1950-1955 hingga 2005-2010 dapat dilihat pada Gambar 1. 


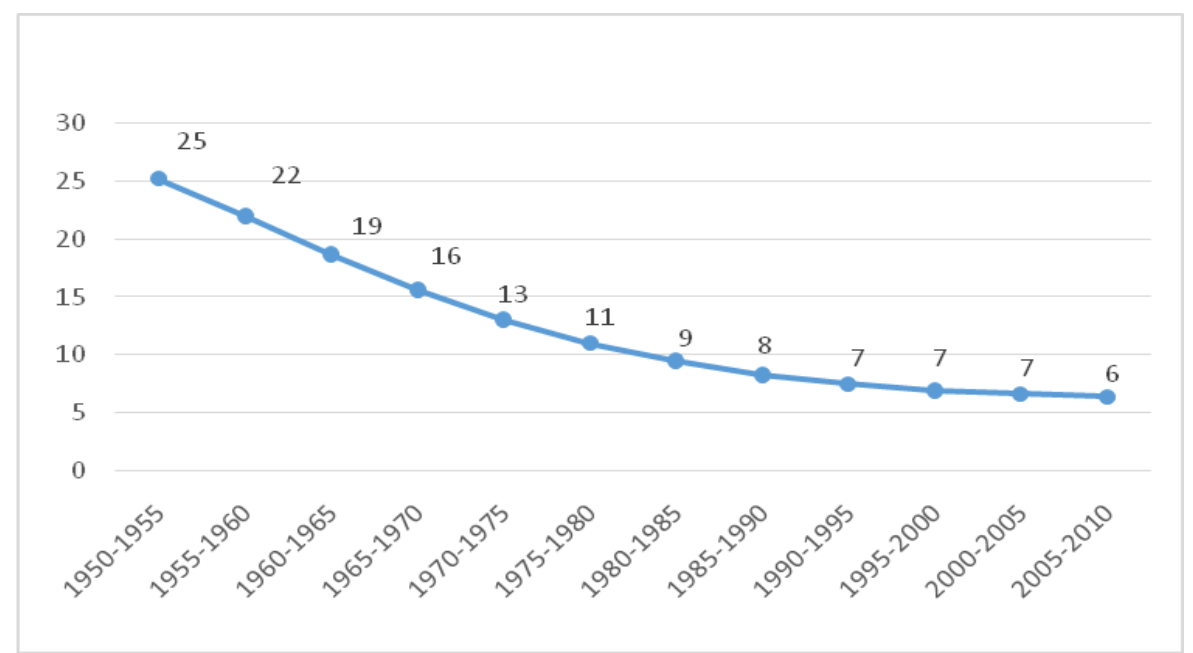

Gambar 1. Estimasi Angka Kematian Kasar di Indonesia Sumber : United Nations, 2013

Berdasarkan Gambar 1 tersebut dapat disimpulkan bahwa CDR di Indonesia mengalami penurunan setiap periodenya. Kematian kasar penduduk Indonesia pada periode 1950-1955 tercatat sebesar 25. Hal itu berarti berarti terjadi 25 kematian setiap 1000 penduduk di pertengahan tahun. Sedangkan pada 2010 tercatat angka kematian kasar di Indonesia sebesar 7 per 1000 penduduk. Keberhasilan

Penurunan angka kematian kasar yang terjadi mengindikasikan semakin membaiknya pelayanan kesehatan baik secara kualitas maupun secara kuantitas. Hal demikian sesuai dengan pendapat yang dikemukakan Iskandar (1977) bahwa usaha meningkatkan fasilitas kesehatan baik secara kualitas maupun kuantitas akan berpengaruh terhadap jumlah kematian. Selain itu, jumlah kematian juga dapat dipengaruhi oleh program kesehatan yang sedang berlaku di masyarakat (Tukiran, 2010).

Pembangunan fasilitas kesehatan dan peningkatan taraf hidup telah dimulai sejak pemerintahan RI pertama dibentuk (Hadi dan Kesuma, 2012). Kemudian pembangunan dilanjutkan dengan tema Pelita (Pembangunan Lima Tahun) pada era Suharto (Alkatiri, 2013). Hal tersebut secara jelas tertulis pada tujuan Pelita I yaitu untuk meningkatkan taraf hidup rakyat dan sekaligus meletakkan dasar-dasar bagi pembangunan dalam tahap berikutnya. Selanjutnya setelah Pelita I pembangunan terus diupayakan dan menjadi salah satu penyebab baiknya kualitas kesehatan di Indonesia (Tukiran, 2010).

Kondisi angka kematian kasar di Indonesia menunjukkan tren selalu mengalami penurunan dari waktu ke waktu dan hal ini berarti menjadi indikasi positif (BPS, 1997; BPS 2006; UN, 2013). Tren positif ini ternayata diproyeksikan akan terus membaik. Meskipun mengalami peningkatan angka kematian kasar tetapi hal ini masih dalam kategori wajar. Di level Asia Tenggara, Brunei, malaysia, Singapura, Filipina dan Timur Leste memiliki angka kematian kasar yang rendah. Indonesia sendiri masih dalam kategori wajar karena nilainya masih di bawah batas normal. 
Tabel 2. Proyeksi Angka Kematian Kasar Negara-Negara Asia Tenggara 2010-2050

\begin{tabular}{|c|c|c|c|c|c|c|c|c|}
\hline \multirow[b]{2}{*}{ Negara } & \multicolumn{8}{|c|}{ Periode Tahun } \\
\hline & $\begin{array}{l}2010- \\
2015\end{array}$ & $\begin{array}{l}2015- \\
2020\end{array}$ & $\begin{array}{l}2020- \\
2025\end{array}$ & $\begin{array}{l}2025- \\
2030\end{array}$ & $\begin{array}{c}2030- \\
2035\end{array}$ & $\begin{array}{l}2035- \\
2040\end{array}$ & $\begin{array}{c}2040- \\
2045\end{array}$ & $\begin{array}{c}2045- \\
2050\end{array}$ \\
\hline Brunei Darussalam & 3 & 3 & 4 & 5 & 6 & 7 & 8 & 9 \\
\hline Cambodia & 6 & 6 & 6 & 6 & 6 & 6 & 7 & 7 \\
\hline Indonesia & 6 & 6 & 7 & 7 & 8 & 8 & 9 & 9 \\
\hline Republik Demokratik Laos & 6 & 5 & 5 & 5 & 5 & 5 & 5 & 6 \\
\hline Malaysia & 5 & 5 & 5 & 6 & 6 & 7 & 7 & 8 \\
\hline Myanmar & 9 & 9 & 9 & 10 & 11 & 11 & 12 & 13 \\
\hline Philippines & 6 & 6 & 6 & 6 & 7 & 7 & 7 & 8 \\
\hline Singapore & 5 & 5 & 6 & 6 & 7 & 8 & 9 & 10 \\
\hline Thailand & 8 & 8 & 9 & 10 & 11 & 12 & 13 & 14 \\
\hline Timor-Leste & 6 & 5 & 5 & 4 & 4 & 3 & 3 & 3 \\
\hline Viet Nam & 6 & 6 & 6 & 7 & 7 & 8 & 9 & 10 \\
\hline South-Eastern Asia & 6 & 7 & 7 & 7 & 8 & 8 & 9 & 10 \\
\hline
\end{tabular}

Sumber:Wold Population Prospect: The 2012 Revision

\subsection{Angka Kematian Bayi}

\subsubsection{Kondisi Mortalitas Bayi di Indonesia dan Proyeksinya}

Mortalitas bayi bayi merupakan salah satu hal yang mencerminkan kondisi derajat kesehatan di suatu daerah. Menurut Hull dan Sunaryo (1978) mortalitas bayi merupakan komponen penting yang mencerminkan indikator sosial ekonomi. Determinan sosial ekonomi ini dapat diwakili oleh pendidikan ibu, kondisi kemiskinan yang terlihat dari pendapatan maupun pengeluaran. Asumsinya, ketika seorang ibu berpendidikan tinggi maka ibu tersebut akan lebih paham mengenai kepentingan kesehatan. Selain itu, kondisi kemiskinan dapat diasumsikan apabila keluarga miskin akan mempengaruhi kondizi gizi semasa hamil dan pemanfaatan pelayanan kesehatan akibat pendapatan yang hanya dapat digunakan untuk memenuhi kebutuhan sehari-hari saja.

Kondisi mortalitas atau kematian bayi di Indonesia menunjukkan tren yang terus menurun setiap periodenya seperti terlihat pada Gambar 2 tentang Infant Mortality Rate (IMR). Penurunan tersebut menandakan peluang untuk meninggalnya bayi antara kelahiran dan sebelum menapai umur satu tahun seperti yang dikemukakan oleh Survei Demografi dan Kesehatan Indonesia (SDKI). Gambar 2 memberikan informasi bahwa terjadi penurunan IMR yang sangat tajam selama 1950-2010. Penurunan tersebut dari 188 kematian per 1000 kelahiran hidup menjadi 29 kematian per 1000 kelahiran hidup. 


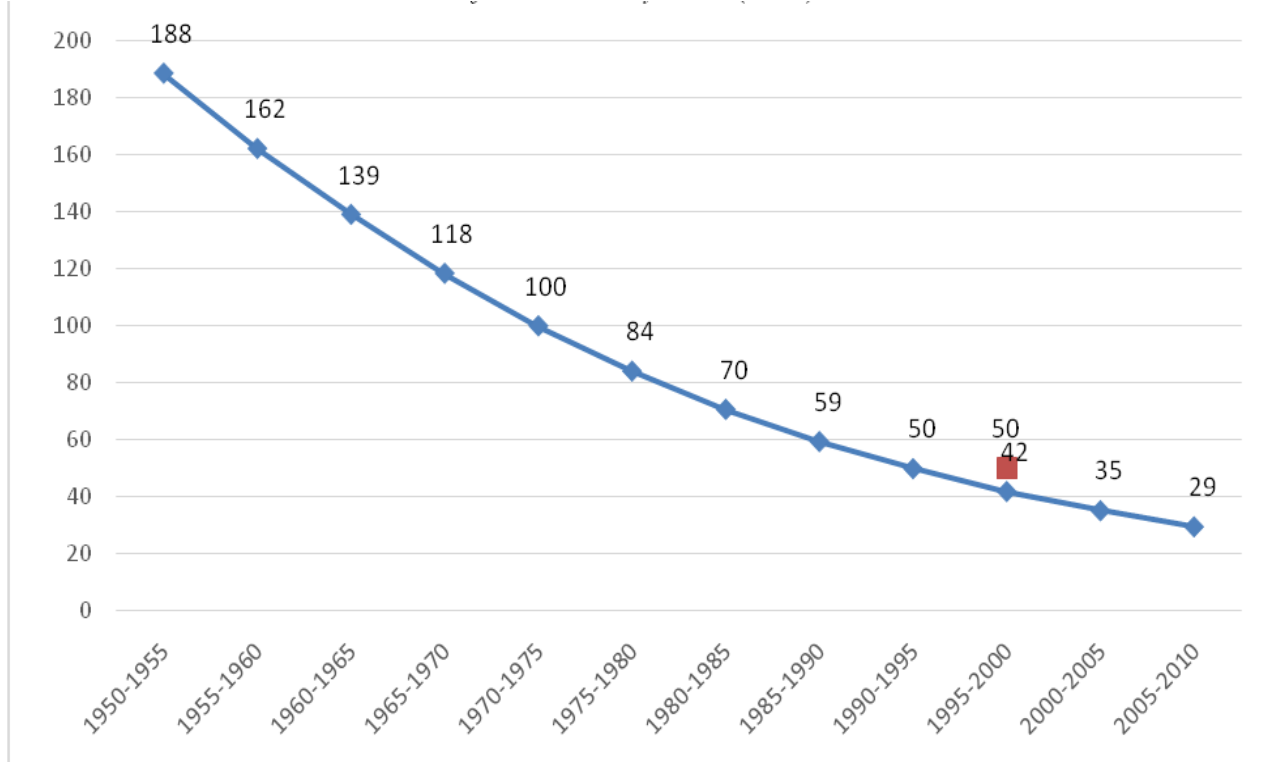

Gambar 2. Estimasi Angka Kematian Bayi di Indonesia Sumber : United Nations, 2013

Apabila ditinjau berdasarkan ketercapaian target MDGs, Gambar 2 menunjukkan ketercapaian target MDGs dengan tercapainya angka IMR kurang dari 50 per 1000 kelahiran hidup pada tahun 2000, maka IMR Indonesia sudah memenuhi target. Berdasarkan gambar tersebut IMR Indonesia sebesar 42 per 1000 kelahiran hidup. Penurunan angka kematian bayi yang terjadi pada setiap periode ini dipengaruhi oleh semakin meningkat dan membaiknya kondisi perekonomian serta sarana dan prasarana kesehatan (UNICEF, 2012). Hal tersebut dapat terjadi karena stake holder khususnya pemerintah memberikan jaminan kesehatan dan persalinan untuk masyarakat kurang mampu. Upaya tersebut dimaksudkan agar masyarakat kurang mampu dapat mengakses pelayanan lesehatan dan persalinan guna menurunkan angka kematian bayi.

Kondisi angka kematian bayi di Indonesia diproyeksikan akan semakin menurun dari tahun 20102050 (Tabel 2). Meskipun demikian tercatat pada periode 2010-2015 sampai 2020-2025 angka kematian bayi di Indonesia diproyeksikan masih lebih tinggi dari rata-rata kematian bayi di Asia Tenggara. Ketertinggalan tersebut menjadi pekerjaan rumah bagi pemerintah untuk lebih menekan lagi angka kematian bayi. Saputra, Fanggidae dan Mafthuchan (2013) menjelaskan bahwa beberapa langkah yang efektif untuk menurunkan angka kematian bayi di Indonesia antara lain dengan penyusunan kebijakan yang tepat. Keterlibatan stakeholder eksekutif, legislatif dan kelompok masyarakat sipil sangat diperlukan dalam penyusunan kebijakan. Selain itu beberapa usulan yang lain antara lain perlunya penempatan kepala puskesmas yang kompeten dan kreatif sebagai ujung tombak pengelola kebijakan/program 


\section{Seminar Nasional dan PIT IGI XVIII 2015}

kesehatan, tersedianya alokasi anggaran khusus yang merupakan bentuk political will pemerintah daerah serta terus menggencarkan budaya perilaku hidup sehat di masyarakat.

Tabel 2. Proyeksi Angka Kematian Bayi Negara-Negara Asia Tenggara 2010-2050

\begin{tabular}{|c|c|c|c|c|c|c|c|c|}
\hline \multirow[b]{2}{*}{ Negara } & \multicolumn{8}{|c|}{ Periode Tahun } \\
\hline & $\begin{array}{l}2010- \\
2015\end{array}$ & $\begin{array}{l}2015- \\
2020 \\
\end{array}$ & $\begin{array}{l}2020- \\
2025 \\
\end{array}$ & $\begin{array}{c}2025- \\
2030\end{array}$ & $\begin{array}{c}2030- \\
2035\end{array}$ & $\begin{array}{l}2035- \\
2040\end{array}$ & $\begin{array}{l}2040- \\
2045\end{array}$ & $\begin{array}{l}2045- \\
2050 \\
\end{array}$ \\
\hline Brunei Darussalam & 4 & 3 & 3 & 2 & 2 & 2 & 1 & 1 \\
\hline Cambodia & 41 & 33 & 28 & 24 & 20 & 18 & 16 & 15 \\
\hline Indonesia & 26 & 23 & 20 & 17 & 15 & 13 & 11 & 10 \\
\hline Republik Demokratik Laos & 36 & 28 & 22 & 18 & 15 & 13 & 12 & 11 \\
\hline Malaysia & 4 & 3 & 3 & 2 & 2 & 2 & 1 & 1 \\
\hline Myanmar & 49 & 45 & 42 & 39 & 36 & 34 & 31 & 29 \\
\hline Philippines & 21 & 19 & 18 & 16 & 15 & 13 & 12 & 11 \\
\hline Singapore & 2 & 1 & 1 & 1 & 1 & 1 & 1 & 1 \\
\hline Thailand & 10 & 8 & 7 & 6 & 6 & 5 & 5 & 4 \\
\hline Timor-Leste & 39 & 31 & 25 & 21 & 18 & 15 & 13 & 12 \\
\hline South-Eastern Asia & 24 & 21 & 19 & 17 & 15 & 13 & 12 & 11 \\
\hline
\end{tabular}

Sumber:Wold Population Prospect: The 2012 Revision

\subsubsection{Mortalitas Bayi per Provinsi di Indonesia}

Data dinamika angka kematian bayi per provinsi di Indonesia tersedia dari tahun 1980-2010 (BPS, 1997 dan BPS, 2006). Angka kematian bayi (AKB) di Indonesia pada tahun 1980 sebesar 109 yang berarti terdapat 109 kematian bayi setiap 1000 kelahiran hidup. Apabila dibandingkan dengan target World Health Organization (WHO) dan International Conference on Population and Development (ICPD) untuk tercapainya AKB sebesar 50 pada tahun 2000 tentunya hal tersebut masih jauh dari target. Tingginya AKB pada tahun 1980 ini dapat dikarenakan belum optimalnya sarana dan prasarana pelayanan kesehatan. Berdasarkan provinsinya, hanya 14 dari provinsi di Indonesia memiliki AKB di bawah AKB Nasional, sedangkan sisanya masih di atas nasional. Pada 1980, nilai AKB terendah adalah DIY yang nilainya sebesar 62. Tingginya nilai AKB disebabkan karena belum meratanya sarana dan prasarana kesehatan terutama di Indonesia bagian timur serta rendahnya kesadaran masyarakat tentang pentingnya kesehatan ibu dan bayi.

Pada 1990 meskipun nilanya turun akan tetapi hanya beberapa provinsi yang menunjukkan kemajuan yang berarti. Penurunan nilai AKB ini juga terjadi sama seperti penurunan yang terjadi pada tahun-tahun sebelumnya (Behm 1983, dalam Seman, 1985). Kemajuan dalam hal penurunan AKB di beberapa provinsi tersebut disebabkan oleh peningkatan kuantitas dan kualitas sarana kesehatan dari tahun-tahun sebelumnya (Santosa, 1990). Tercatat hanya dua provinsi yang berhasil menunjukkan progres yang baik yaitu DKI Jakarta dan DI Yogyakarta. Nilai AKB untuk keduanya masing-masing sebesar 43 
(DKI Jakarta) dan 42 (DIY). Pada tahun 2000 beberapa provinsi telah menunjukkan kemajuan dalam mengurangi angka kematian bayi. hal ini dibuktikan dari semakin turunnya angka kematian bayi di Indonesia menjadi 47 per 1000 kelahiran hidup. Meskipun secara rata-rata Indonesia telah memenuhi target dari ICPD dan WHO pada tahun 2000 dan 2015, akan tetapi jika dilihat secara provinsi capaian tersebut belum dikatakan memuaskan.

Berdasarkan Gambar 3, provinsi yang telah mencapai target ICPD hanya sebesar 9 provinsi di Indonesia. DKI Jakarta dan DIY sama-sama memiliki nilai AKB yang rendah yaitu sebesar 25 kematian per 1000 kelahiran. Untuk capaian di DIY hal tersebut dikarenakan beberapa hal antara lain aksesibilitas ke faskes sangat baik, sarana prasarana transportasi yang memadai, sarana pelayanan kesehatan yang tersebar, jumlah tenaga yang cukup banyak dan bervariasi, serta adanya keterpaduan unit-unit pelayanan dan jajaran kesehatan pemerintah memegang peranan penting dalam hal ini (Dinas kesehatan DIY, 2011). Sedangkan di DKI program kesehatan dikuatkan dengan dukungan anggaran yang memadai.

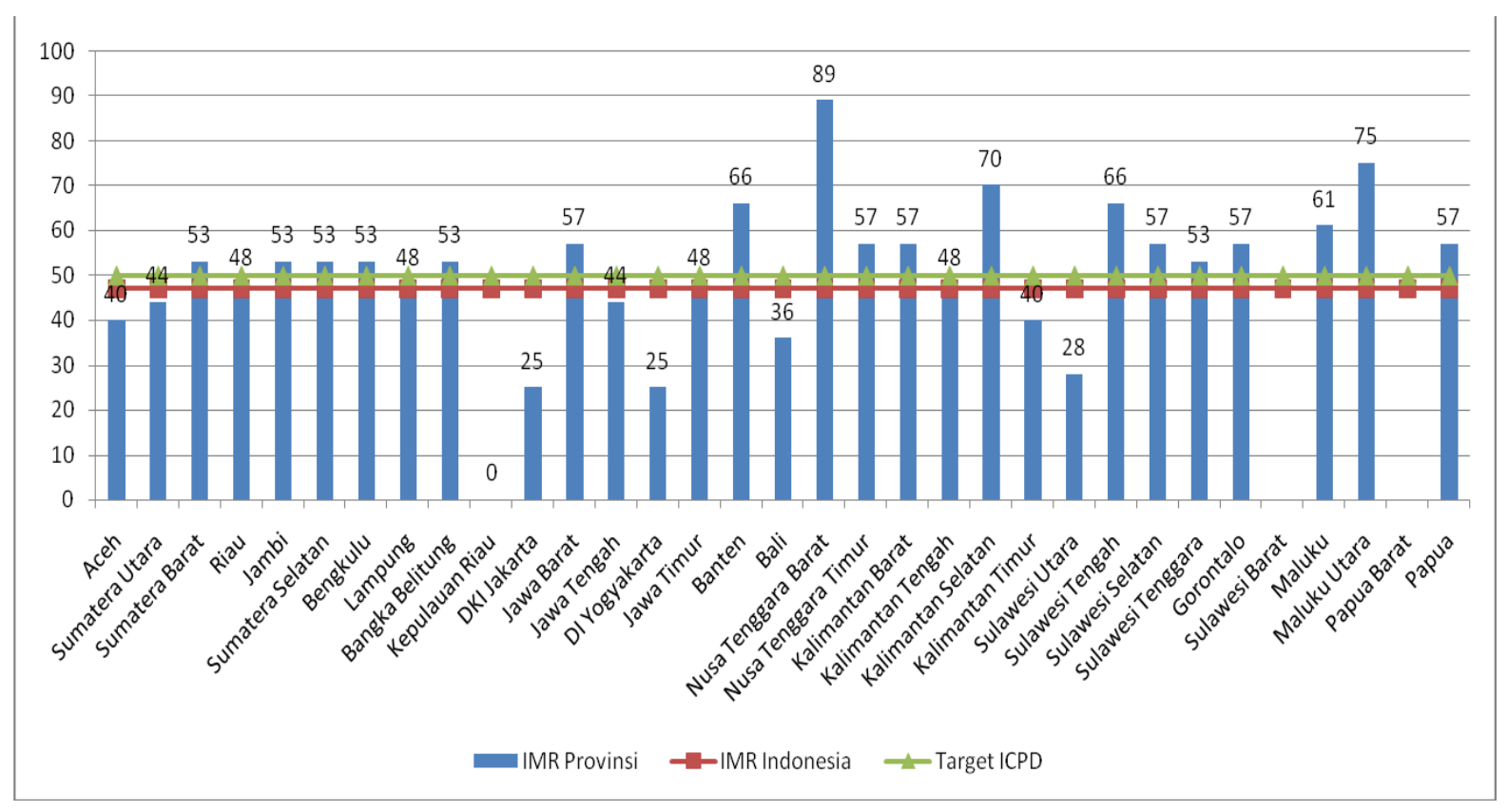

Gambar 3. Estimasi Angka Kematian Bayi Per Provinsi di Indonesia 2000 Sumber : Badan Pusat Statistik, 1997 dan 2006

Kondisi pencapaian angka kematian bayi di Indonesia juga menunjukkan ketimpangan. Gambar 3 menunjukkan bahwa antara nilai tertinggi dan terendah di Indonesia rentangnya sangat jauh. Pada tahun 2000 nilai AKB di DIY sebesar 25 sedangkan di NTB nilai AKB sebesar 89. Rentang yang sangat tinggi tersebut merupakan gambaran adanya ketertinggalan yang ekstrim di NTB dalam bidang kesehatan. Berdasarkan penelitian Suardi (2009) tingginya kematian bayi dikarenakan budaya masyarakat dalam 


\section{Seminar Nasional dan PIT IGI XVIII 2015}

memperhatikan pola hidup sehat dan gizi bagi bayi. Beberapa budaya yang diduga memicu terjadinya tingginya angka kematian bayi di NTB antara lain perkawinan selarian, persalinan yang ditangani oleh dukun, bayi diberi nasi pakpak (nasi yang telah dikunyah terlebih dahulu oleh ibunya), dan adanya pantangan makanan selama hamil dan setelah melahirkan. Selain itu sarana dan prasarana di NTB dalam masalah kesehatan juga jauh tertinggal dengan DIY baik dari segi kualitas maupun kuantitasnya. Selain itu menurut UNICEF (2012) tingginya kematian bayi dipengaruhi oleh rendahnya pendidikan ibu, kebersihan rumah dan lingkungan, pendapatan, serta akses ke pelayanan kesehatan.

Perhatian pemerintah dalam penurunan angka AKB dapat dikatakan sangat baik. Hal ini ditunjukkan dari penurunan AKB yang sangat drastis dari tahun 2000, dimana pada tahun 2000 AKB Indonesia sebesar 47 dan pada tahun 2010 menjadi 26 pada tahun 2010. Hal tersebut tidak lepas dari kemajuan pembangunan di beberapa provinsi mengalami perbaikan yang berkomitmen untuk menurunkan angka kematian bayinya. Provinsi dengan AKB paling tinggi pada tahun 2000 yaitu NTB mengalami kemajuan yang berarti. Bergesernya posisi Nusa Tenggara Barat menjadi provinsi dengan AKB tertinggi ini tak luput dari upaya pemerintah mengalokasikan dana APBD Dinas Kesehatan untuk upaya penurunan AKI dan AKB (Faulia, 2010).

Target yang ditetapkan ICPD pada tahun 2015 yaitu tercapainya AKB sebesar 35 kematian bayi setiap 1000 kelahiran hidup. Secara nasional, Indonesia optimis dapat mencapai target tersebut karena berdasarkan proyeksi dari UN pada periode 2010 nilai AKB di Indonesia sebesar 27 dan pada tahun 2015 nilai AKB diproyeksi sebesar 23. Permasalahannya adalah pada kesenjangan antar provinsi dimana pada beberapa provinsi pembangunan dalam bidang kesehatan belum optimal.

\subsection{Angka Kematian Balita}

Angka Kematian Balita (Child Mortality Rate/CMR) merupakan jumlah kematian anak dibawah 5 tahun per 1000 anak umur yang sama pada pertegahan tahun. Angka kematian anak menggambarkan kondisi kesehatan lingkungan yang langsung mempengaruhi tingkat kesehatan anak. Tren CMR dari periode 1950-1955 hingga 2005-2010 mengalami penurunan terus-menerus pada setiap periodenya. Penurunan tersebut terlihat pada Gambar 4. 


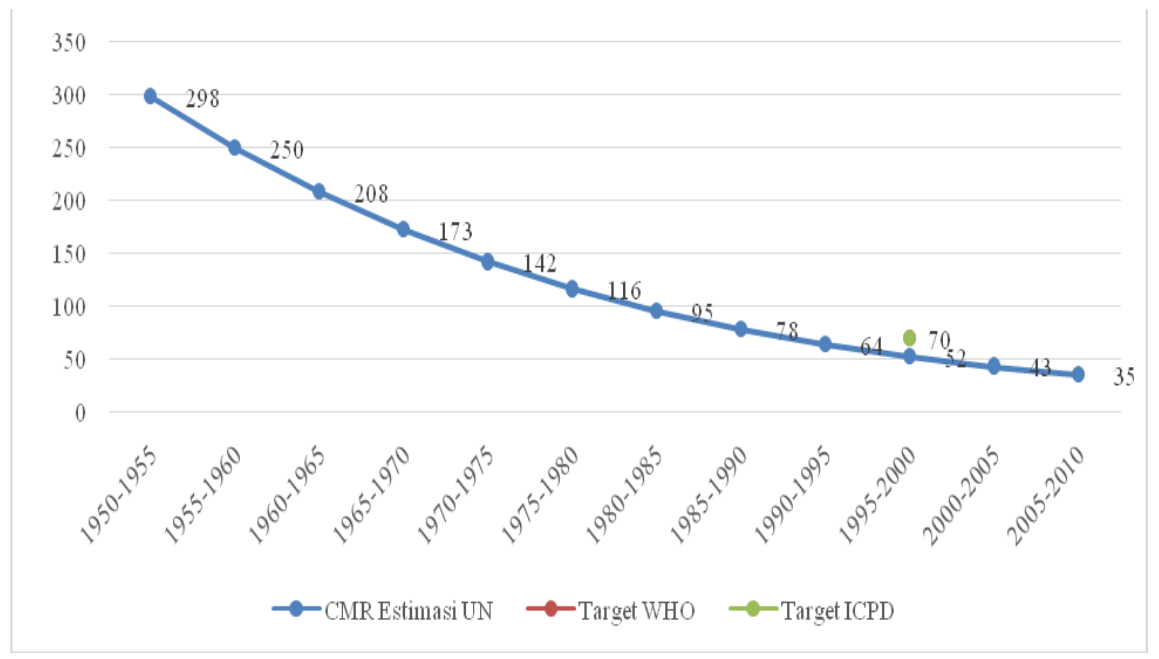

Gambar 4. Estimasi Angka Kematian Balita di Indonesia

Sumber : United Nations, 2013

Penurunan CMR yang terlihat pada Gambar 4 telah mencapai target yang ditetapkan WHO dan ICPD. Target yang ditetapkan WHO dan ICPD pada tahun 2000 adalah 70 kematian anak dibawah 5 tahun per 1000 anak dengan umur yang sama. Berdasarkan grafik diatas dapat diketahui bahwa target yang ditetapkan WHO dan ICPD telah tercapai dengan CMR ketercapaian sebesar 64 kematian anak dibawah 5 tahun per 1000 anak dengan umur yang sama. Meskipun demikian, penurunan angka kematian anak harus tetap menjadi perhatian di Indonesia. Beberapa langkah yang dapat dilakukan untuk mengurangi angka kematian anak antara lain menyediakan akses kesehatan yang baik, kualitas perawatan kelahiran dan manajemen penyakit masa kanak-kanak yang baik serta dukungan kesehatan lingkungan yang baik. Dukungan tersebut misalnya dengan penyediaan air dan sanitasi yang bersih, pengawasan penyakit menular, serta pemberian nutrisi ibu yang baik.

Target yang ditentukan oleh ICPD pada tahun 2015 adalah pencapaian nilai AKB sebesar 45 kematian per 1000 anak umur yang sama pada pertengahan tahun. Berdasarkan Tabel 3, diketahui bahwa pada tahun 2015 Indonesia diproyeksikan sudah memehuhi target ICPD. Posisi Indonesia dibandingkan dengan negara lain di Asia Tenggara tergolong baik. Sampai pada periode 2020, Indonesia masih berada di atas rata-rata pencapaian negara Asia Tenggara. Selanjutnya setelah tahun 2020 keberhasilan Indonesia dalam menurunkan angka kematian balita diproyeksikan sejajar dengan rata-rata pencapaian angka kematan balita di negara Asia Tenggara. Pada level Asia Tenggara, negara dengan pencapaian penurunan angka kematian terbaik adalah Singapura (UN, 2013). 
Seminar Nasional dan PIT IGI XVIII 2015

Tabel 3. Proyeksi Angka Kematian Bayi Negara-Negara Asia Tenggara 2010-2050

\begin{tabular}{|c|c|c|c|c|c|c|c|c|}
\hline \multirow[b]{2}{*}{ Negara } & \multicolumn{8}{|c|}{ Periode tahun } \\
\hline & $\begin{array}{l}2010- \\
2015\end{array}$ & $\begin{array}{l}2015- \\
2020\end{array}$ & $\begin{array}{l}2020- \\
2025\end{array}$ & $\begin{array}{c}2025- \\
2030\end{array}$ & $\begin{array}{l}2030- \\
2035\end{array}$ & $\begin{array}{c}2035- \\
2040\end{array}$ & $\begin{array}{l}2040- \\
2045\end{array}$ & $\begin{array}{l}2045- \\
2050\end{array}$ \\
\hline Brunei Darussalam & 5 & 4 & 3 & 2 & 2 & 2 & 2 & 1 \\
\hline Cambodia & 51 & 42 & 35 & 30 & 26 & 23 & 21 & 19 \\
\hline Indonesia & 31 & 27 & 23 & 20 & 18 & 15 & 13 & 11 \\
\hline Republik Demokratik Laos & 45 & 34 & 26 & 21 & 17 & 15 & 14 & 13 \\
\hline Malaysia & 5 & 4 & 4 & 3 & 2 & 2 & 2 & 1 \\
\hline Myanmar & 63 & 58 & 53 & 49 & 45 & 41 & 38 & 35 \\
\hline Philippines & 27 & 25 & 23 & 21 & 19 & 17 & 15 & 14 \\
\hline Singapore & 2 & 2 & 2 & 1 & 1 & 1 & 1 & 1 \\
\hline Thailand & 12 & 10 & 9 & 7 & 7 & 6 & 5 & 5 \\
\hline Timor-Leste & 49 & 38 & 30 & 24 & 20 & 18 & 15 & 14 \\
\hline Viet Nam & 20 & 18 & 16 & 15 & 13 & 12 & 11 & 11 \\
\hline South-Eastern Asia & 30 & 26 & 23 & 21 & 18 & 16 & 15 & 13 \\
\hline
\end{tabular}

Sumber:Wold Population Prospect: The 2012 Revision

\subsection{Angka Harapan Hidup}

\subsubsection{Dinamika Angka Harapan Hidup Indonesia dan Proyeksinya}

Angka Harapan Hidup ( $\mathrm{AHH}$ ) adalah perkiraan jumlah tahun hidup dari individu yang tinggal di suatu daerah tertentu. Kemenkes (2014) mengasumsikan besarnya AHH tersebut tidak disertai adanya perubahan pola kematian. Besarnya AHH di suatu daerah mengggambarkan kondisi sosial ekonomi di daerah tersebut terkait dengan tingkat kesejahteraan yang ada (BPS, 2008). Bahkan angka harapan hidup umumnya digunakan sebagai indikator kemajuan suatu Negara (Kabir, 2008).

Dinamika AHH di Indonesia menunjukkan tren positif dimana dari periode 1950-1955 sampai periode 2005-2010 menunjukkan kenaikan terus-menerus. Peningkatan AHH tersebut terjadi akibat adanya upaya pemerintah mengenai strategi pembangunan nasional dengan menempatkan sumberdaya manusia sebagai perspektif pembangunan dengan meningkatkan semua indikatornya. Salah satu indikator yang digunakan adalah AHH (Kemenkes, 2014). Selain itu, Kabir (2008) menyatakan bahwa di Negaranegara berkembang kenaikan AHH ini dipengaruhi oleh faktor-faktor sosial ekonomi yang meliputi kesehatan, pendidikan, sanitasi, lingkungan, pendapatan, tingkat kemiskinan, akses air bersih, dan riwayat penyakit. 


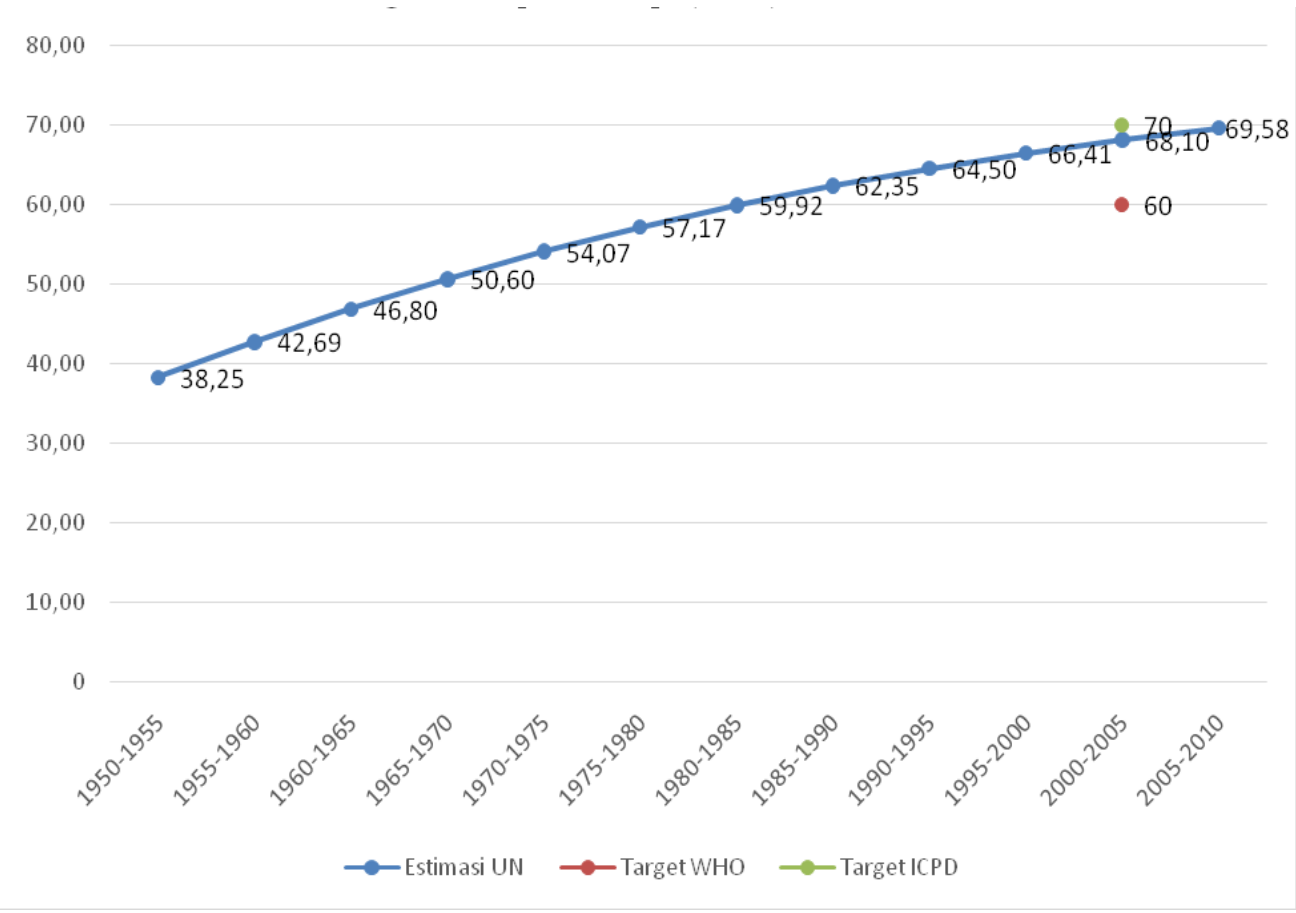

Gambar 5. Estimasi Angka Harapan Hidup di Indonesia Sumber : United Nations, 2013

Gambar 5 juga menjelaskan bahwa Indonesia telah mencapai target AHH yang telah ditetapkan oleh WHO dan ICPD. Target yang ditetapkan oleh ICPD adalah penduduk di suatu negara mencapai nilai AHH sebesar 60 tahun pada tahun 2000. Sedangkan pada tahun 2000 AHH Indonesia sebesar 66,41. Begitupula dengan target yang ditetapkan oleh ICPD dimana target yang ditetapkan dengan nilai AHH pada tahun 2005 sebesar 65 bagi negara dengan tingkat mortalitas yang tinggi. Sementara pencapaian nilai AHH di Indonesia pada tahun 2005 sebesar 68,10.

Target AHH juga tercapai jika dilihat berdasarkan ketercapaian berdasarkan jenis kelaminnya. Nilai AHH perempuan pada tahun 2000 telah mencapai 68,42 dan pada tahun 2005 nilai AHH sebesar 70,11. Sedangkan untuk laki-laki, nilai AHH laki-laki pada tahun 2000 sebesar 64,43 dan pada tahun 2005 sebesar 65,11. hal ini merupakan sinayl yang baik karena telah dibahas di awal bahwa AHH merupakan indikator kasar dari kesejahteraan wilayah.

Tercapainya target AHH Indonesia dikarenakan adanya kesepakatan "Health for All" pada tahun 2000 yang memberikan intervensi besar bagi Negara-negara berkembang seperti Indonesia di bidang kesehatan (Matthews dan Diamond, 1999). Negara berkembang seperti Indonesia berlomba-lomba untuk meningkatkan derajat kesehatan penduduknya yang diwujudkan dengan berbagai kebijakan. Hal ini terbukti dengan adanya peningkatan kualitas dan kuantitas sarana serta prasarana di bidang kesehatan. Bahkan pemerintah secara khusus membuat undang-undang tentang kesehatan. Dalam Pasal 14 UU No. 


\section{Seminar Nasional dan PIT IGI XVIII 2015}

36 Tahun 2009 tentang Kesehatan pemerintah berkomitmen secara penuh untuk menyelenggarakan urusan kesehatan secara menyeluruh. Pasal tersebut menyatakan bahwa,

" pemerintah bertanggungjawab merencanakan, mengatur, menyelenggarakan, membina, dan mengawasi penyelenggaraan upaya kesehatan yang merata dan terjangkau oleh masyarakat."

Upaya lain yang dilakukan negara-negara berkembang, termasuk Indonesia, untuk meningkatkan angka harapan hidup adalah dengan meningkatkan imunisasi untuk anak-anak (Matthews dan Diamond, 1999). Kegiatan imunisasi dilakukan sebagai tindakan preventif yang dilakukan untuk mempertahankan status kesehatan penduduk. Kegiatan imunisasi ini diperbaharui peraturannya dengan keluarnya Peraturan Menteri Kesehatan Republik Indonesia No 42 Tahun 2013.

Tingginya AHH di Indonesia diproyeksikan akan terus meningkat sampai periode 2045-2050. Meskipun demikian posisi Indonesia masih di bawah rata-rata AHH yang dimiliki oleh negara-negara di Asia Tenggara. Bahkan berdasarkan Tabel 4, nilai AHH kita lebih rendah daripada AHH Kamboja. Hal tersebut seharusnya menjadi pelecut bagi Indonesia untuk terus meningkatkan nilai AHH.

Tabel 4. Proyeksi Angka Harapan Hidup Negara-Negara Asia Tenggara 2010-2050

\begin{tabular}{|c|c|c|c|c|c|c|c|c|}
\hline \multirow[b]{2}{*}{ Negara } & \multicolumn{8}{|c|}{ Periode Tahun } \\
\hline & $\begin{array}{r}2010- \\
2015\end{array}$ & $\begin{array}{r}2015- \\
2020\end{array}$ & $\begin{array}{r}2020- \\
2025\end{array}$ & $\begin{array}{r}2025- \\
2030\end{array}$ & $\begin{array}{r}2030- \\
2035\end{array}$ & $\begin{array}{r}2035- \\
2040\end{array}$ & $\begin{array}{r}2040- \\
2045\end{array}$ & $\begin{array}{r}2045- \\
2050\end{array}$ \\
\hline Brunei Darussalam & 78,45 & 79,42 & 80,37 & 81,29 & 82,14 & 82,89 & 83,60 & 84,28 \\
\hline Cambodia & 71,63 & 73,46 & 74,99 & 76,29 & 77,40 & 78,42 & 79,33 & 80,17 \\
\hline Indonesia & 70,72 & 71,73 & 72,67 & 73,56 & 74,43 & 75,28 & 76,12 & 76,95 \\
\hline Republik Demokratik Laos & 68,08 & 70,21 & 72,11 & 73,76 & 75,15 & 76,36 & 77,45 & 78,45 \\
\hline Malaysia & 74,93 & 75,83 & 76,70 & 77,56 & 78,42 & 79,26 & 80,09 & 80,90 \\
\hline Myanmar & 65,08 & 65,92 & 66,70 & 67,43 & 68,14 & 68,81 & 69,46 & 70,09 \\
\hline Philippines & 68,63 & 69,41 & 70,16 & 70,87 & 71,56 & 72,23 & 72,93 & 73,63 \\
\hline Singapore & 82,20 & 83,09 & 83,94 & 84,75 & 85,53 & 86,28 & 87,01 & 87,73 \\
\hline Thailand & 74,27 & 75,24 & 76,17 & 77,09 & 77,99 & 78,87 & 79,72 & 80,52 \\
\hline Timor-Leste & 67,30 & 69,45 & 71,18 & 72,59 & 73,80 & 74,88 & 75,91 & 76,90 \\
\hline Viet Nam & 75,87 & 76,62 & 77,38 & 78,13 & 78,84 & 79,49 & 80,08 & 80,65 \\
\hline South-Eastern Asia & 71,41 & 72,39 & 73,30 & 74,16 & 74,98 & 75,77 & 76,53 & 77,25 \\
\hline
\end{tabular}

Sumber:Wold Population Prospect: The 2012 Revision

\subsubsection{Dinamika Angka Harapan Hidup per Provinsi Indonesia}

Ukuran kematian yang komplementer dengan angka kematian bayi adalah angka harapan hidup (Kasto, 1992). Berdasarkan provinsinya, pada tahun 1970 hanya 12 provinsi yang besarnya AHH diatas AHH nasional. Nilai AHH paling tinggi berada di Provinsi Papua dengan nilai sebesar 56.7. Tingginya AHH di Provinsi Papua ini salah satunya dipengaruhi oleh budaya konsumsi makanan yang sehat karena menurunkan risiko terkenanya penyakit. Sedangkan provinsi dengan AHH terendah adalah Provinsi Nusa Tenggara Barat dengan nilai sebesar 35. Rendahnya AHH di Nusa Tenggara Barat ini dipengaruhi oleh banyaknya penduduk yang tidak dapat mengakses hak untuk sehat atau fasilitas kesehatan. Selain itu, 
rendahnya kualitas pendukung kesehatan berupa sanitasi, air bersih dan gizi menyebabkan rendahnya AHH.

Perubahan nilai AHH meskipun meningkat akan tetapi pertambahannya hanya sedikit demi sedikit. Hal itu terjadi pada tahun 19980 dan tahun 1990. Sedangkan pada tahun 2000, peningkatan AHH cukup baik hasilnya. Hal ini dapat dilihat dari telah tercapainya sebagian besar target dari ICPD tentang batas minimal nilai AHH sebesar 60 tahun pada tahun 2000. dari seluruh provinsi yang ada, hanya dua provinsi yang belum mencapai target tersebut yaitu NTB dan Maluku (Gambar 6). Sedangkan pada 2010 peningkatan nilai AHH tetap terjadi dengan DKI Jakarta dan DIY sebagai provinsi dengan nilai AHH tertinggi.

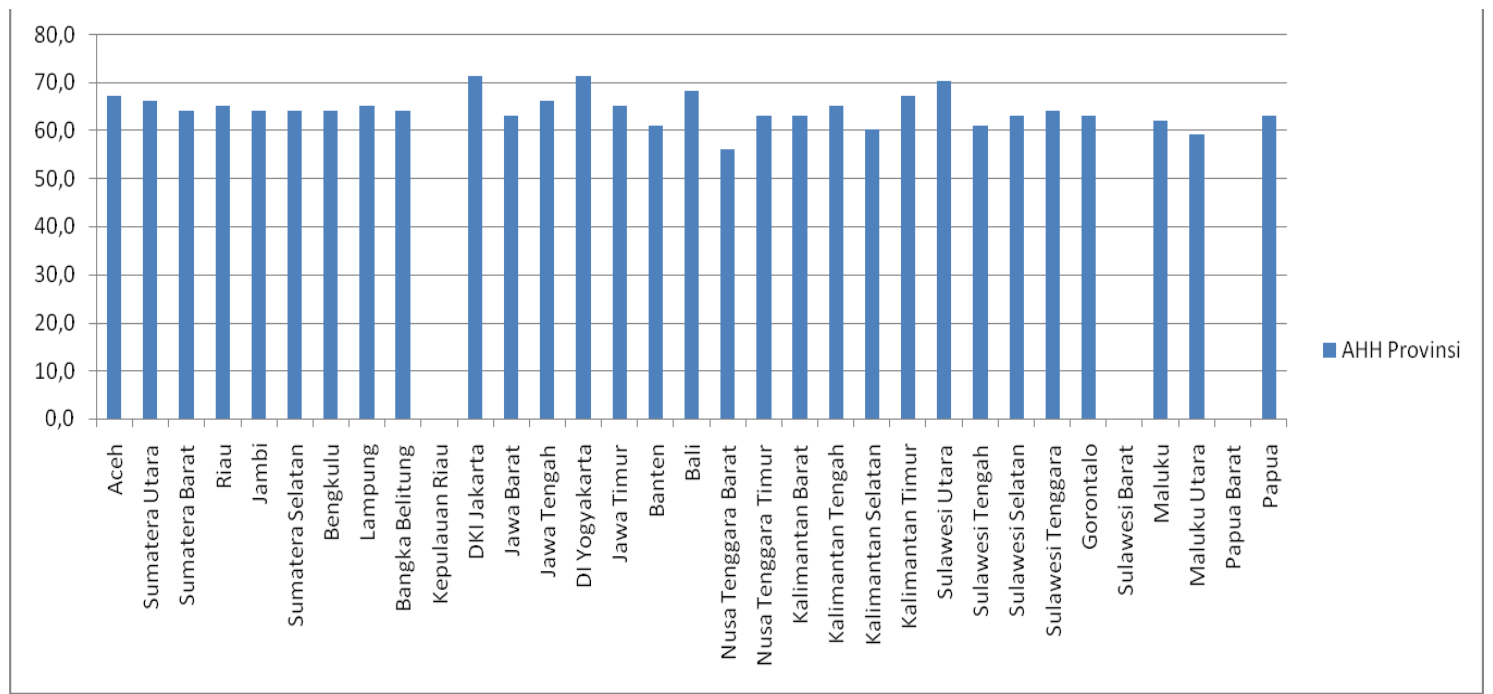

Gambar 6. Estimasi Angka Harapan Hidup di Indonesia Sumber : BPS, 1997 dan 2006

\section{KESIMPULAN}

Hasil penelitian menunjukkan bahwa indikator kematian di Indonesia terus mengalami kenaikan setiap periodenya. Angka kematian kasar di Indonesia menunjukkan penurunan yang cukup drastis. Hal ini berarti derajat kesehatan di Indonesia menunjukkan perbaikan di setiap periodenya. Secara nasional indikator mortalitas seperti angka kematian bayi, angka kematian anak dan harapan hidup menujukkan trend yang positif dimana target dari ICPD dan WHO telah terpenuhi. Tren positif tersebut juga diproyeksikan akan seperti itu sampai 2050. Akan tetapi jika dilihat berdasarkan provinsinya, beberapa provinsi belum memenuhi target tersebut. Hal ini merupakan pekerjaan rumah ke depan bagi pemerintah untuk memperbaiki derajat kesehatan penduduknya. 


\section{Seminar Nasional dan PIT IGI XVIII 2015}

\section{DAFTAR PUSTAKA}

Alkatiri, Z. 2013. The Words Of Magic Used During The Soeharto's Indonesian New Order Military Regime Era 1980-1997. Asian Journal Of Social Sciences \& Humanities. Vol. 2. No. 1. February 2013. ISSN: 2186-8492

Biro Pusat Statistik. 1997. Estimasi Fertilitas, Mortalitas Dan Migrasi : Hasil Survei Penduduk Antar Sensus (SUPAS) 1995. Jakarta : Badan Pusat Statistik.

Biro Pusat Statistik. 2006. Estimasi Fertilitas, Mortalitas Dan Migrasi : Hasil Survei Penduduk Antar Sensus (SUPAS) 2005. Jakarta : Badan Pusat Statistik.

Dinas Kesehatan DIY. 2011. Profil Kesehatan Daerah Istimewa Yogyakarta Tahun 2010. Yogyakarta:

Dinas Kesehatan Daerah Istimewa Yogyakarta

Hadi, D.W. dan Kasuma, G. 2012. Propaganda Orde Baru 1966-1980. Verleden, Vol. 1, No.1. Desember 2012: 1 - 109 .

Hull dan Sunaryo. 1978. Level and Trens of Infant and Child Mortality in Indonesia, Working Paper in Indonesian Population Dynamic Project. Yogyakarta: Pusat dan Studi Kependudukan UGM

Iskandar, N. 1977. Demografi Arti \& Tujuan. Jakarta: Lembaga Demografi Fakultas Ekonomi Universitas Indonesia

Mantra, I. B. 2000. Demografi Umum. Pustaka Pelajar: Yogyakarta

Kabir, M. 2008. Determinants of Life Expectancy in Developing Country. The Journal of Developing Areas. Volume 41 No. pp. 185-204

Kasto. 1993. Analisa perkembangan Kependudukan Menurut Sensus Penduduk 1990 : Dinamika Mortalitas Indonesia. Yogyakarta: Kantor Menteri Negara Kependudukan dan Lingkungan Hidup, Pusat Penelitian Kependudukan Universitas Gadjah Mada.

Kemenkes RI. 2014. Profil Kesehatan Ibu dan Anak Tahun 2013. Jakarta: Kementerian Kesehatan Republik Indonesia

Matthews dan Diamond. 1999. The Expanded Programme on Immunisation: Mortality Consequences and Demographic Impact in Developing Countries. Genus, 55. Volume 1/2 pp. 73-100

Peraturan Menteri Kesehatan Republik Indonesia No 42 Tahun 2013

Santosa, H. 1990. Faktor-faktor Penentu Kematian Bayi di Indonesia, Suatu Analisa Data SUPAS 1985. Tesis. Yogyakarta: Fakultas Kedokteran UGM

Saputra, Fanggidae, \& Mafthuchan. 2013. Efektif Kebijakan Daerah Menurunkan Angka Kematian Ibu dan Bayi. Jurnal Kesehatan Masyarakat Nasional. Vol. 7, No. 12, Juli 2013. Halaman 531-537.

Seman, S. 1985. Faktor-faktor yang Mempengaruhi Tingkat Kematian Bayi di Daerah Sulawesi Selatan Tenggara. Tesis. Yogyakarta: Fakultas Kedokteran UGM 


\section{Seminar Nasional dan PIT IGI XVIII 2015}

Suardi. 2009. Analisis Distribusi Spasial Kematian Bayi di Kabupaten Lombok Timur Provinsi Nusa Tenggara Barat Tahun 2008. Tesis. Yogyakarta: Fakultas Kedokteran UGM

Tukiran. 2010. Kependudukan. Jakarta: Universitas Terbuka

UNICEF. 2012. Ringkasan Kajian Kesehatan Ibu dan Anak. UNICEF Indonesia

United Nations. 1993. Population and Development Planning. New York: United Nation

United Nations. 2013. Wold Population Prospect: The 2012 Revision. New York: United Nations

United Nations. 2013. World Mortality Report 2013. New York: United Nations

UNFPA. Programme of Action - Adopted at the International Conference on Population and Development, Cairo, 5-13 September 1994. New York: United Nations Population Fund. ISBN 0-89714-696-4

Utomo, B. 1985. Mortalitas: Pengertian dan Contoh Kasus di Indonesia. Fakultas Kesehatan Masyarakat UI: Jakarta

Wood, S, N, dan Nisbet, R, M. 1990. Estimation of Mortality Rates in Stage-Structured Population. Springer-Verlag: Berlin 